\title{
OBRONA PRACY DOKTORSKIEJ MGRA MIKOLAJA TARKOWSKIEGO
}

W dniu 10 grudnia 2012 roku odbyła się na Wydziale Prawa i Administracji Uniwersytetu Gdańskiego publiczna obrona pracy doktorskiej mgra Mikołaja Tarkowskiego. Podstawą przewodu była rozprawa zatytułowana Adwokatura wileńska 1918-1939. Promotorem w przewodzie doktorskim był prof. zw. dr hab. Dariusz Szpoper, recenzentami - prof. dr hab. Zbigniew Naworski z Uniwersytetu Mikołaja Kopernika w Toruniu oraz prof. dr hab. Andrzej Wrzyszcz z Uniwersytetu Marii Curie-Skłodowskiej w Lublinie.

Komisja Rady Wydziału podjęła jednomyślnie uchwałę o nadaniu mgrowi Mikołajowi Tarkowskiemu stopnia doktora nauk prawnych.

JACEK WA£DOCH (Gdańsk) 